\title{
ANALISIS KESALAHAN SISWA SMP KELAS IX PADA MATERI BANGUN RUANG SISI DATAR SAAT MENYELESAIKAN SOAL BERPIKIR KRITIS
}

\author{
Muhammad Jafar Sidik ${ }^{1}$, Heris Hendriana ${ }^{2}$, Ratna Sariningsih ${ }^{3}$ \\ 1,2,3 IKIP Siliwangi, Jln Terusan Jendral Sudirman Cimahi, Jawa Barat, Indonesia \\ 1.jafarsidiktipar31@gmail.com, ${ }^{2}$ ratnasari_ning@ymail.com, ${ }^{3}$ hendriana@ stkipsiliwangi.ac.id
}

\begin{abstract}
This research belongs to qualitative descriptive research which attempts to describe the analysis of student error in solving the problem of critical thinking mathematics on the material of building flat side space. Subject in this research is SMPN 5 Cimahi students of class IX-B which in this case student have studied material of building flat side space. The instruments used consisted of tests of critical mathematical thinking skills and student interviews. The results showed that the location of the mistakes made by the students is a mistake of concepts, error translation and strategy error. Factors that cause the error because they do not understand simple concepts, do not know the purpose of the problem, can not translate the problem into the mathematical sentence, can not finish the mathematical sentence.
\end{abstract}

Keywords: error, critical thinking skills of matematics, flat side space geometry

\begin{abstract}
Abstrak
Penelitian ini merupakan penelitian deskriptif kualitatif yang berupaya untuk mendeskripsikan analisis kesalahan siswa SMP kelas I-X pada materi bangun ruang sisi datar dalam menyelesaikan soal kemampuan berpikir kritis matematik. Subyek dalam penelitian ini adalah siswa kelas IX-B SMPN 5 Cimahi yang dalam hal ini siswa sudah mempelajari materi bangun ruang sisi datar. Instrumen yang digunakan terdiri dari tes kemampuan berpikir kritis matematik dan wawancara siswa. Hasil penelitian menunjukkan bahwa letak kesalahan yang dilakukan siswa adalah kesalahan konsep, kesalahan terjemahan dan kesalahan strategi. Faktor penyebab kesalahannya karena tidak paham konsep-konsep sederhana, tidak mengetahui maksud soal, tidak bisa menerjemahkan soal ke dalam kalimat matematika, tidak bisa menyelesaikan kalimat matematika.
\end{abstract}

Kata Kunci: kesalahan, kemampuan berpikir kritis matematik, bangun ruang sisi datar

How to cite: Sidik, M. J., Hendriana, H., Sariningsih, R. (2018). Analisis Kesalahan Siswa SMP Kelas IX pada Materi Bangun Ruang Sisi Datar saat Menyelesaikan Soal Berpikir Kritis. JPMI - Jurnal Pembelajaran Matematika Inovatif, 1 (5), 837-846.

\section{PENDAHULUAN}

Ilmu matematika memang selalu berkembang tidak pernah habis dari waktu ke waktu, seiring berkembangnya jaman ilmu matematikapun semakin beragam. Tetapi hal itu justru bisa membuat dampak masalah apabila tidak disertai dengan kesiapan dari pendidik atau peserta didik. Padahal sangat pentingnya pembelajaran matematika di sekolah yang akan menjadi bekal mereka untuk digunakan dalam kehidupan sehari-hari. Matematika adalah pengantar dasar bagi kehidupan, sehingga matematika di selalu pelajari disetiap jenjang pendidikan. Salah satu ilmu matematika yang cukup penting dalam kehidupan adalah kemampuan 
berpikir kritis matematik yang salahsatu indikatornya untuk menganalisis suatu pernyataan atau argumen dan mengenal adanya hubungan yang logis antara masalah satu dengan yang lainnya, yang jika dipelajari bisa digunakan dalam berbagai bidang hal untuk menyelesaikan suatu masalah. Hal ini sejalan dengan pendapat Sariningsih \& Herdiman (2017) yang menyatakan hampir dalam semua disiplin ilmu maupun dalam dunia kerja mensyaratkan seseorang dituntut untuk bisa menganalisis dan mensitesis berbagai konsep serta harus mampu melihat hubungan antar konsep satu dengan yang lainnya untuk digunakan dalam upaya menyelesikan permasalahan. Selain itu, hal tersebut dibuktikan dengan tujuan pendidikan dan visi bidang studi matematika menurut Sumarmo dkk. (2012) yang didalamnya memuat kemampuan matematik, sikap kritis, kreatif dan cermat, obyektif dan terbuka, menghargai keindahan matematika, serta rasa ingin tahu dan senang belajar matematika. Namun pada kenyataannya di lapangan banyak siswa disetiap jenjang pendidikan menganggap bahwa matematika itu pelajaran yang sulit. Siswa menganggap matematika banyak menimbulkan bahkan menambah masalah yang sulit untuk dipecahkan, sehingga dampaknya membuat hasil belajar siswa menjadi kurang baik yang berakibat pada kemampuan berpikir kritis matematik siswa tidak bisa berkembang. Sejalan dengan pendapat Aripin (2015) menyatakan, sudah menjadi rahasia umum bahwa bagi kebanyakan siswa yang beranggapan bahwa matematika mata pelajaran yang cukup sukar untuk dipelajari. Hal tersebut berdampak buruk terhadap cara berpikir siswa yang lebih mencari cara yang instan dalam memahami suatu masalah, dimana siswa hanya menggunakan konsep yang telah diberikan gurunya. Selain itu, Hendriana (2012) mengungkapkan bahwa para siswa lebih cenderung menghafalkan konsep-konsep matematika, seringkali dengan cara mengulangulang dan menyebutkan definisi yang diberikan guru atau yang tertulis dalam buku, tanpa berusaha untuk memahami maksud dari isi konsep tersebut.

Hal serupa di temukan di SMPN 5 CIMAHI dari hasil wawancara dengan guru terkait, mengungkapkan bahwa dalam kemampuan berpikir kritis siswanya memang masih bisa dikatakan rendah, siswanya hanya mampu menghapal konsep dari apa yang di dapat dari gurunya, dan belum bisa sampai menggunakan dan manipulasi bahan-bahan yang dipelajari ke dalam situasi baru. Siswa juga hanya mampu mengerjakan soal ketika hapal terhadap rumus yang diberikan oleh gurunya. Sehingga siswa hanya bisa mengerjakan soal yang memang sudah biasa mereka temukan ketika pembelajaran berlangssung dengan gurunya.

Arti berpikir kritis sendiri menurut Sumarmo et al. (2012) kemampuan berpikir kritis adalah kemampuan yang meliputi: 1) Menganalisis dan mengevaluasi argumen dan bukti. 2) Menyusun klarifikasi. 3) Membuat pertimbangan yang bernilai. 4) Menyusun penjelasan berdasarkan data yang relevan dan yang tidak relevan. 5) Mengidentifikasi dan mengevaluasi asumsi.

Gokhale (Hendriana dkk, 2017) mendefinisikan istilah berpikir kritis sebagai berpikir yang melibatkan kegiatan menganalisis, menyintesa, dan mengevaluasi konsep. Pengertian ini menunjukan bahwa kemampuan berfikir kritis seseorang makin tinggi jika ia mampu menganalisis kebenaran sampai pada mengevaluasi konsep pada suatu masalah. Berdasarkan hal tersebut tampak bahwa benar berpikir kritis matematik memang sangat penting dimiliki oleh siswa. Sejalan dengan pendapat (Mardiyanti, Afrilianto, \& Rohaeti, 2018) menyatakan bahwa mengembangkan kemampuan berpikir kritis dalam pembelajaran Matematika meupakan hal yang sangatlah penting. Maka dari itu diperlukannya perbaikan dalam proses pembelajaran karena faktor yang bisa membuat keberhasilan siswa dalam pelajaran matematika menurut Fatmawati (2014) yaitu tidak hanya berpatok pada kemampuan siswa sendiri namun didukung oleh faktor guru dan juga model pembelajaran yang digunakan di 
dalam kelas. Sejalan dengan apa yang diungkapkan oleh Sukmadinata (2007) dalam pembelajaran gurupun harus mengenal dan memahami siswa dengan baik, memahami tahap perkembangan yang sudah dicapainya, keahlian-keahliannya, keunggulan dan kekurangannya, hambatan serta masalah yang dihadapi serta faktor-faktor lain yang mungkin bisa mempengaruhinya. Sebagaimana tertulis dalam Depdiknas (2007) tentang Standar Penilaian Pendidikan, kegiatan dalam penilaian yang dilakukan guru adalah mengolah memanfaatkan hasil penilaian untuk memperbaiki sistem pembelajaran. Indraningtias \& Wijaya (2017) mengungkapkan diperlukan adanya kegiatan pembelajaran di kelas yang berorientasi pada kemampuan berpikir kritis siswa yaitu kegiatan mengidentifikasi dan memahami masalah, mengatur strategi dan menentukan solusi, menginferensi, dan mengevaluasi. Salah satu yang bisa dilakukan untuk mengetahui masalah belajar yang dialami siswa yaitu dengan menganalisis kesalahan hasil belajar siswa.

Penelitian ini dimaksudkan untuk menganalisis kesalahan-kesalahan yang dilakukan siswa berdasarkan aspek kemampuan siswa. Dengan adanya penelitian ini, diharapkan dapat memberikan informasi serta gambaran penyebab siswa mengalami kesalahan dalam mengerjakan soal matematika kepada guru matematika. Sehingga guru mampu melihat kekurangan siswa untuk bahan evaluasi dalam pembelajaran.

\section{METODE}

Penelitian ini dilaksanakan di kelas IX-B SMPN 5 Cimahi pada bulan April tahun ajaran 2017/2018. Metode ini adalah deskriptif kualitatif, Jenis ini dipilih karena bertujuan untuk menggambarkan analisis kesalahan siswa dalam menyelesaikan soal-soal berpikir kritis matematik pada materi bangun ruang sisi datar. Subjek yang dipilih yaitu siswa kelas IX-B. Data penelitian yang dikumpulkan berupa informasi tentang kesalahan yang dilakukan peserta didik dalam menyelesaikan soal matematika. Instrumen penelitian ini terdiri dari 5 soal uraian disertai dengan wawancara agar dapat terlihat jelas letak kesalahan yang dilakukan oleh siswa.

Penyajian data menggunakan teknik triangulasi, adapun proses triangulasi pada penelitian ini yaitu menyajikan data wawancara berupa subjek penelitian dan data hasil kerja siswa, membandingkan antara data wawancara dengan data hasil kerja siswa, analisis data menggunakan reduksi data, penyajian data dan kesimpulan.

\section{HASIL DAN PEMBAHASAN}

\section{Hasil}

Langkah pertama yang dilakukan dalam penelitian ini adalah penyusunan soal instrumen yang kemudian instrumen soal tersebut akan didiskusikan terlebih dahulu dengan dosen pembimbing untuk diberikan masukan-masukan yang memang diperlukan untuk melancarkan penelitian ini. Kemudian soal tersebut di ujikan kepada siswa di salah satu sekolah yang ada di cimahi. Soal tersebut akan diujikan kepada siswa kelas IX dengan waktu 80 menit, setelah itu hasil uji coba diolah dan dianalisis berdasarkan rubrik penskoran. 
Tabel 1. Statistik deskriptif skor tes soal kemampuan berpikir kritis matematik

\begin{tabular}{|c|c|c|c|c|c|}
\hline Indikator & $\begin{array}{c}\mathbf{A} \\
\text { Mengevaluasi } \\
\text { situasi } \\
\text { matematik } \\
\text { secara reflektif }\end{array}$ & $\begin{array}{c}\text { B } \\
\text { Memeriksa } \\
\text { kebenaran } \\
\text { pertanyaan luas } \\
\text { prisma pada } \\
\text { permasalahan yang } \\
\text { nyata }\end{array}$ & $\begin{array}{c}\text { C } \\
\text { Mengenalisis } \\
\text { dan } \\
\text { menjelaskan } \\
\text { pertanyaan, } \\
\text { jawaban dan } \\
\text { argumen }\end{array}$ & $\begin{array}{c}\text { D } \\
\text { Mencari } \\
\text { alternatif } \\
\text { penyelesaian } \\
\text { masalah }\end{array}$ & $\begin{array}{c}\mathbf{E} \\
\text { Memeriksa } \\
\text { kebenaran pada } \\
\text { volume kubus } \\
\text { pada } \\
\text { permasalahan } \\
\text { yang nyata }\end{array}$ \\
\hline SMI & 3 & 10 & 7 & 7 & 13 \\
\hline Rata-Rata & 2,31 & 5,60 & 2,97 & 4,34 & 3,14 \\
\hline Presentase & $77 \%$ & $56 \%$ & $42,4 \%$ & $62 \%$ & $24,1 \%$ \\
\hline
\end{tabular}

Sangat terlihat jelas bahwa kemampuan berpikir kritis matematik siswa masih cukup rendah terlihat dari dua indikator $\mathrm{C}$ dan $\mathrm{E}$ yang memberikan hasil presentasenya kurang dari $50 \%$ yang sangat terlihat jelas adalah di indikator E yang hanya menghasilkan presentase $24,1 \%$, dalam hal ini jenis indikator tersebut adalah memeriksa kebenaran volume kubus pada permasalahan yang nyata. Banyak faktor yang menyebabkan kesalahan ini terjadi. Faktor tersebut adalah kesalahan dalam memahami suatu konsep yang berlaku, kesalahan mengubah/ menerjemahkan bahasa/ ungkapan matematik, kesalahan dalam memahami perhitungan, dan terkecoh dengan soal tanpa melihat maksud yang diinginkan soal serta siswa tidak mengetahui langkah penyelesaian soal. Berdasarkan data yang telah didapat, maka selanjutnya diambil subyek penelitian dengan cara memberikan peringkat yang sesuai dari data siswa yang telah di olah. Kemudian sampel dibagi menjadi tiga kelompok, yang terdiri dari kelompok atas, sedang, dan bawah. Pengambilan subyek dilakukan secara acak pada masing-masing kelompok. Dari kelompok atas diambil subyek penelitian I dan subjek penelitian II. Kemudian dari kelompok sedang diambil subyek penelitian IIIdan subyek penelitian IV. Dan untuk kelompok bawah diambil subjek penelitian V.

Hasil pekerjaan subjek penelitian dipilih 1 soal untuk dianalisis. Setiap subyek penelitian kemudan dianalisis hasilnya, dan dari hasil analisis diberikan penguatan melalui triangulasi berdasarkan dari hasil wawancara siswa.

Lerner (Abdurrahman, 1999) mengemukakan tentang kesalahan-kesalahan umum yang dilakukan oleh anak dalam mengerjakan soal-soal matematika, yaitu kurangnya dari pengetahuan tentang simbol-simbol matematika, kurangnya pemahaman tentang nilai tempat, penggunaan proses yang keliru, kesalahan perhitungan, dan tulisan yang tidak dapat dibaca sehingga membuat siswa melakukan kekeliruan.

Sedangkan untuk materi geometri, Azia (2004) dalam penelitiannya menemukan bahwa kesalahan-kesalahan yang paling banyak dilakukan siswa pada saat mengerjakan soal adalah kesalahan konsep, kesalahan strategi dan kesalahan terjemahan.

Berdasarkan pendapat para ahli diatas maka dapat ditarik kesimpulan bahwa masih terdapat banyak kesalahan-kesalahan yang dilakukan oleh siswa, sehingga kesalahan-kesalahan 
tersebut menjadi acuan bagi peneliti untuk memperjelas lebih jauh kesalahan-kesalahan yang sering dilakukan oleh siswa SMP. Kemudian dari hasil tersebut dapat terlihat dan menjadikan gambaran tentang kesalahan sisiwa dalam menyelesaikan soal-soal kemampuan berpikir kritis matematik, siswa masih banyak melakukan kesalahan.

\section{Pembahasan}

Setelah melakukan penelitian dan menganalisis data hasil penelitian, peneliti berhasil mendapatkan data dan banyaknya siswa melakukan kesalahan-kesalahan dalam menyelesaikan soal dalam masing-masing tipe indikatornya, berikut adalah gambar beserta hasil awancara siswa sehingga terlihat lebih jelas letak kesalahan yang dilakukan oleh siswa. Kesalahan tersebut meliputi:

a. Kesalahan terjemahan

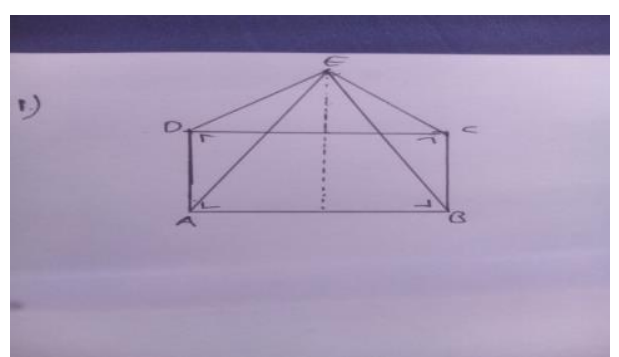

Gambar 1. Jawaban soal nomor 1

Kesalahan yang dilakukan subyek pada gambar 1 adalah tidak menuliskan langkah yang diminta pada soaldan tidak menujukan unsur-unsur limas segi empat. Padahal di dalam soal siswa diperintahkan untuk menunjukan unsur-unsur limas segi empat, tetapi subyek hanya mampu menggambar tanpa menyebutkan unsur-unsurnya.

Wawanacara:

$\mathrm{G}$ : “apakah mengalami kesulitan atau mendapat masalah untuk no.1 dalam pengerjaannya?"

S1 : "lumayan pak, saya kurang paham dengan soalnya."

G : "baik, coba dilihat kembali dan cermati maksud soalnya"

S1 : "baik, akan saya usahakan pak untuk memjawabnya."

G : "silahkan coba lagi, dan jangan mudah menyerah"

Berdasarkan hasil wawancara terlihat penyebab siswa melakukan kesalahan dalam menjawab nomor 1 adalah bingung dengan maksud soal, sehingga siswa tidak bisa menuliskan langkahlangkah yang diminta.

b. Kesalahan konsep

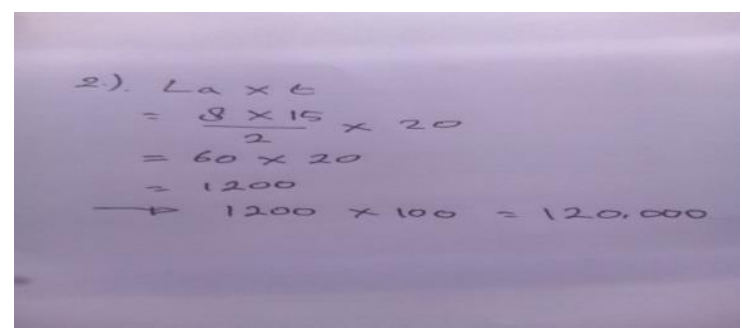

Gambar 2. Jawaban Soal Nomor 2 
Kesalahan yang dilakukan subyek pada gambar 2 adalah subyek mengerjakan tanpa menggunakan konsep yang seharusnya. Terlihat siswa hanya mampu langsung menggunakan rumus tanpa menyimak dengan baik pertanyaannya, siswa belum mampu mengubah konsep yang telah di pelajari kedalam situasi yang baru.

Wawancara:

G : "Apakah ada masalah untuk soal no.2 ?"

S2 : "saya bisa mengerjakan tapi tidak tahu benar atau salahnya, pak"

G : "apa yang membuatmu tidak yakin?"

S2 : "saya masih sulit untuk cara pengerjaannya pak. Terlebih saya belum mampu dalam memahami soalnya"

G : "apakah kamu sudah pernah menemukan soal yang hampir mirip seperti ini?"

S2 : "biasanya soal prismanya tidak seperti ini, jadi saya tidak terlalu paham dengan dengan soalnya pak."

G : "caba cari alternatif lain agar kamu mendapatkan jawabannya!"

S2 : "baik pak akan saya coba lagi."

Berdasarkan hasil wawancara siswa di atas, subyek menjawab bisa mengerjakannya meskipun tidak yakin dengan jawabannya dan tidak mengetahui langkah-langkah pengerjaan atau rencana penyelesaian soal.

c. Kesalahan konsep

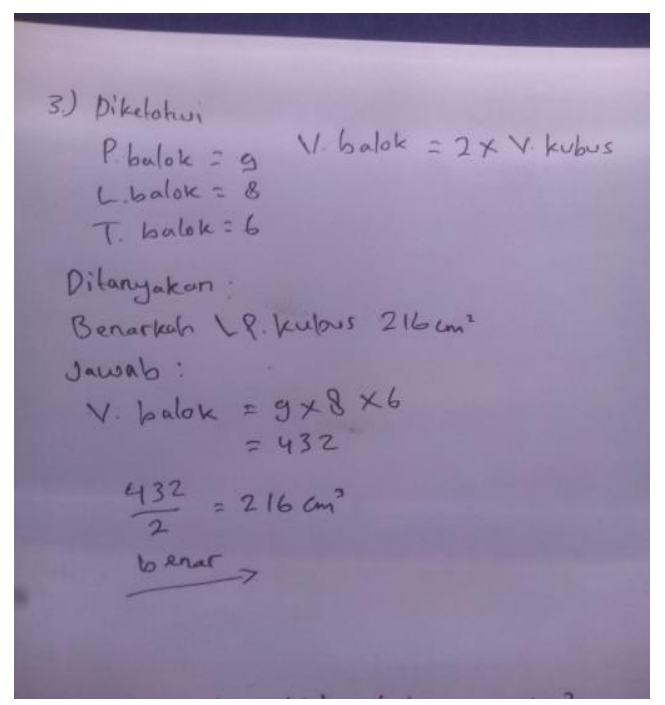

Gambar 3. Jawaban Soal Nomor 3

Kesalahan yang dilakukan subyek pada gambar 3 adalah dalam menyusun rencana, karena subyek tidak memperhatikan dengan baik pertanyaan dan terkecoh oleh soal. Subyek hanya mampu menjawab sampai pada volume kubus, sedangkan yang ditanyakan luas permukaan kubus.

Wawanacara:

G : "apakah terdapat masalah untuk soal yang sedang di kerjakan ini ?"

S3 : "saya kurang paham pak dengan soalnya."

G : "coba dibaca dengan baik soalnya. Kemudian lihat apa yang ditanyakan ?"

S3 : "benarkah luas permukaan kubus $216 \mathrm{~cm}^{2}$ " 
G : "ya, selanjutnya apa yang dikejakan terlebih dahulu?"

S3 : "saya harus mencari dulu volume kubusnya, tapi saya bingung bagaimana cara mencari luas permukaan kubusnya"

G : "coba pikirkan kembali kira- kira bagaimana cara mencari luas permukaan kubusnya!"

S3 : "baik pak akan saya coba untuk menjawabnya lagi."

Berdasarkan wawancara bahwa penyebab kesalahan yang dilakukan subyek dalam menjawab soal nomor 3 adalah tidak bisa cara mencari luas permukaan kubus tersebut. Sehingga subyek tidak bisa menyelesaikan soal dengan benar.

d. Kesalahan strategi

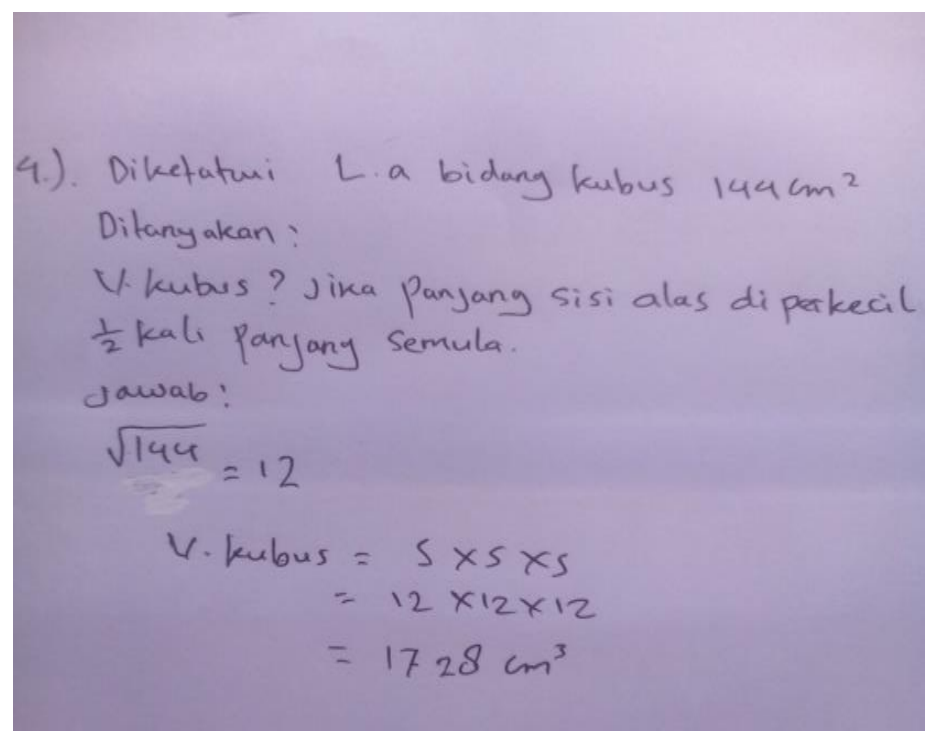

Gambar 4. Jawaban Soal Nomor 4

Kesalahan yang dilakukan subyek pada gambar no 4 adalah subyek kurang tepat dalam langkah mengerjakan soal, sehingga jawabannya pun menjadi salah. Terlihat bahwa subyek kesulitan dalam memahami soal, Subyek langsung menyelesaikan soal dengan menggunakan rumus volume kubus, tanpa memperhatikan unsur yang harus dicari terlebih dahulu.

Wawanacara:

G : "apakah terdapat masalah untuk soal no.4?"

S4 : "lumayan pak, tapi saya bisa mengerjakannya, benarkan pak?"

G : "kenapa kamu tidak yakin dengan jawaban mu sendiri?"

S4 : "saya bisa mengerjakan soalnya, tapi masih ragu pak, dengan jawaban saya."

G : "cobabaca lagi soalnya.apa yang ditanyakan, kemudian perhatikan unsur kubus yang belum diketahui!"

S4 : "baik pak akan saya coba sekali lagi." 
Berdasarkan wawancara bahwa penyebab kesalahan yang dilakukan subyek dalam menjawab soal nomor 4 adalah kurang mengerti dengan pertanyaannya dan tidak fokus terhadap unsur kubus yang belum diketahui, sehingga subyek salah dalam memberikan langkah jawaban.

e. Kesalahan konsep

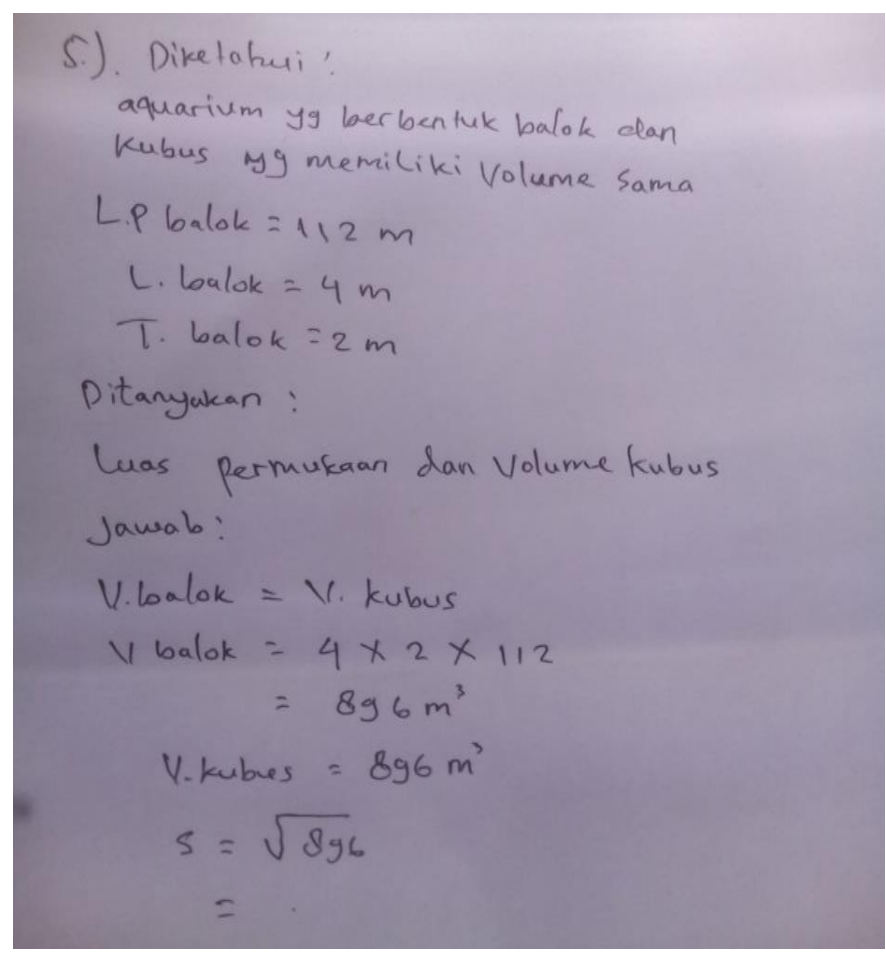

Gambar 5. Jawaban Soal Nomor 5

Kesulitan yang dilakukan subyek pada gambar no 5 adalah subyek sulit mencari panjang baloknya dan langsung menawab dengan konsep volume balok, sehingga jawabannya pun menjadi salah dan cenderung mengasal. Seharusnya siswa mencari panjang balok dari luas permukaannya, sehingga unsur balok pun menjadi lengkap. Setelah itu baru bisa dicari volume baloknya dan menjawab pertanyaan berikutnya dengan tepat.

Wawanacara:

G : “apakahterdapatmasalahuntuksoal no.5?”

S5 : "pusing pak,soalnya terlalu berbelit-belit. Saya susah untuk bisa menjawabnya."

G : "apakah kamu tidak bisa mencerna dengan baik maksud soalnya?"

S5 : "sedikit saya paham pak, tapi cukup berbelit soalnya."

G : "cobabacasoalnya dan kerjakan bertahap agar jawabannya bisa ketemu, dan kamu mampu menyelesaikannya dengan baik."

S5 : "baik pak akan saya coba lagi."

G : "semangat! Coba lagi dan pantang menyerah."

Berdasarkan wawancara bahwa penyebab kesalahan subyek dalam menyelesaikan soal nomor 5 adalah karena subyek menganggap terlalu rumit soal yang diberikan. 
Dari hasil penelitian menunjukan bahwa tingkat kemampuan siswa perlu dilatih kembali dalam menguasai pertanyaan dan dalam memberikan jawaban soal kemampuan berpikir kritis, sampai pada nantinya siswa mampu memberikan jawaban serta menganalisis suatu pertanyaan dan argumentasi dari suatu masalah. Maka untuk kedepannya perlu ada upaya untuk mengatasi masalah itu semua salahsatunya dengan pendekatan pembelajaran karena menurut Herdiman (2017), pendekatan pembelajaran diupayakan untuk bisa mengaktifkan siswa dalam mengembangkan daya nalar matematik siswa sehingga siswa mampu mengembangkan dan mengevaluasi suatu argumentasi.

\section{KESIMPULAN}

Berdasarkan tujuan awal peneliti yaitu untuk menganalisis kesalahan siswa kelas IX-B SMPN 5 Cimahi pada saat menjawabsoal-soal pada materi bangun ruang sisi datar, sampai pada akhirnya peneliti melihat bahwa masih terdapat banyak kesalahan yang dilakukan oleh dalam menjawab soal. Maka peneliti mengambil kesimpulan kesalahan yang dilakukan siswa adalah sebagai berikut:

1. Kesalahan konsep

a. Kesalahan dalam langkah pengerjaan, subyek langsung menerapkan rumus tanpa mencari unsur yang masih belum diketahui, penyebab terjadinya kesalahan ini adalah siswa hanya hapal rumus tanpa paham penggunaannya.

b. Kesalahan langsung menjawab tanpa menuliskan rumus, penyebab terjadinya kesalahan siswa tidak memahami konsep rumus, sehingga siswa hanya mampu mengira-ngira tanpa mengetahui langkah pengerjaansoalnya.

2. Kesalahan terjemahan

Adalah kesalahan dalam menerjemah soal kedalam bentukungkapan matematik atau kesalahan dalam memberikan makna suatu pernyataan matematika.

3. Kesalahan strategi

Adalah kesalahan dalam langkah memulai pengerjaan, sehingga siswa menjadi keliru dalam memberikan jawaban atau respon terhadap soal.

\section{SARAN}

Adapun saran bagi siswa, diharapkan mampu meningkatkan kemampuannya dalam menyelesaikan soal-soal berpikir kritis matematiknya terlebih pada indikator menganalisis dan menjelaskan pertanyaan, jawaban dan argumen. Agar nantinya bisa bermanfaat untuk kehidupan di lingkungannya dan ketika dalam pembelajaran di sekolah bisa mendapat nilai yang lebih baik lagi. dan bagi peneliti selanjutnya, penelitian ini dapat dilanjutkan dengan meneliti analisis kemampuan berpikir kritis matematik yang lebih memahami isi permasalahan secara umum lainnya melaui diskusi dengan guru terkait sehingga mampu melihat lebih jauh masalah-masalah yang dihadapi siswa di sekolahnya.

\section{UCAPAN TERIMA KASIH}

Peneliti menyadari dalam penyusunan artikel jurnal ini tidak akan selesai tanpa bantuan dari berbagai pihak. Karena itu pada kesempatan ini peneliti sangatberterimakasih kepada Dr. H. Heris Hendriana, M.Pd., selaku dosen pembimbing utama dan Ratna Sariningsih, M.Pd., selaku pembimbing pendamping. Atas bimbingan beliau, peneliti dapat menyelesaikan penelitian dan penulisan artikel ilmiah ini. 


\section{DAFTAR PUSTAKA}

Abdurrahman, M. (1999). Pendidikan Bagi Anak Berkesulitan Belajar. Jakarta: PT. Rineka Cipta.

Aripin, U. (2015). Meningkatkan Kemampuan Pemahaman Matematik Siswa SMP Melalui Pendekatan Pembelajaran Berbasis Masalah. Jurnal Ilmiah UPT P2M STKIP Siliwangi, 2(1), 128-136. Retrieved from https://ejournal.stkipsiliwangi.ac.id/index.php/p2m/article/view/170

Azia, Y. M. (2004). Upaya Mengatasi Kesulitan Siswa Belajar Geometri dengan Pengajaran Remidial Kelompok dan Remedial Bersama di Sekolah Lanjutan Tingkat Pertama(Http://digilib.upi.edu/pasca/available/etd-1011106-131035/ di akses tanggal 20 Juni 2018)

Depdiknas. (2007). Standar Penilaian Pendidikan. Jakarta: Depdiknas.

Fatmawati, H. (2014). Analisis Berpikir Kritis Siswa dalam Pemecahan Masalah Matematika Berdasarkan Polya pada Pokok Bahasan Persamaan Kuadrat. Jurnal Elektronik Pembelajaran Matematika, 2(9), 911-922.

Hendriana, H., Rohaeti, E.,E., Sumarmo, U. (2017). Hard Skills dan Soft Skills. Bandung: Aditama.

Hendriana, H. (2012). Pembelajaran Matematika Humanis Dengan Metaphorical Thinking Untuk Meningkatkan Kepercayaan Diri Siswa. Jurnal Infinity, 1(1), 90-103. https://doi.org/10.22460/infinity.v1i1.9

Herdiman, I. (2017). Peenerapan Pendekatan Open-Ended untuk Meningkatkan Matematik Siswa SMP. Jes-Mat, 3(2), 195-204.

Indraningtias, D. A., \& Wijaya, A. (2017). Pengembangan Perangkat Pembelajaran Berbasis Pendekatan. Jurnal Pendidikan Matematika, 6(5), 24-36.

Mardiyanti, D. O., Afrilianto, M., \& Rohaeti, E. E. (2018). Analisis Kemampuan Berpikir Kritis Matematik Siswa SMP pada Materi Segitiga dengan Pendekatan Metaphorical Thinking. JPMI, 1(3), 427-434. https://doi.org/10.22460/jpmi.v1i3.427-434

Sariningsih, R., \& Herdiman, I. (2017). Mengembangkan Kemampuan Penalaran Statistik dan Berpikir Kreatif Matematis Mahasiswa Melalui Pendekatan Open-ended. Jurnal Riset Pendidikan Matematika, 4(42), 239-246. https://doi.org/10.21831/jrpm.v4i2.16685

Sukmadinata, N. S. (2007). Pengembangan Kurikulum Teori dan Praktek. Bandung: PT. Remaja Rosdakarya.

Sumarmo, U., Hidayat, W., Zukarnaen, R., Hamidah, M., \& Sariningsih, R. (2012). KEMAMPUAN DAN DISPOSISI BERPIKIR LOGIS, KRITIS, DAN KREATIF MATEMATIK (Eksperimen terhadap Siswa SMA Menggunakan Pembelajaran Berbasis Masalah dan Strategi Think-Talk-Write). Jurnal Pengajaran Matematika Dan Ilmu Pengetahuan Alam, 17(1), 17. https://doi.org/10.18269/jpmipa.v17i1.228 